\title{
High time-resolution chemical characterization of the water-soluble fraction of ambient aerosols with PILS-TOC-IC and AMS
}

\author{
H. Timonen ${ }^{1}$, M. Aurela ${ }^{1}$, S. Carbone ${ }^{1}$, K. Saarnio ${ }^{1}$, S. Saarikoski ${ }^{1}$, T. Mäkelä ${ }^{1}$, M. Kulmala ${ }^{2}$, V.-M. Kerminen ${ }^{1,2}$, \\ D. R. Worsnop ${ }^{1,2,3}$, and R. Hillamo ${ }^{1}$ \\ ${ }^{1}$ Air Quality Research, Finnish Meteorological Institute, P.O. Box 503, 00101 Helsinki, Finland \\ ${ }^{2}$ Department of Physics, University of Helsinki, P.O. Box 64, 00014 University of Helsinki, Finland \\ ${ }^{3}$ Aerodyne Research, Inc., 45 Manning Road, Billerica, MA 01821-3976, USA
}

Received: 23 March 2010 - Published in Atmos. Meas. Tech. Discuss.: 15 April 2010

Revised: 1 July 2010 - Accepted: 11 August 2010 - Published: 18 August 2010

\begin{abstract}
A particle-into-liquid sampler (PILS) was coupled with a total organic carbon analyzer (TOC) and two ion chromatographs (IC) to enable high time-resolution measurements of water-soluble ions and water-soluble organic carbon (WSOC) by a single sampling and analytical setup. The new high time-resolution measurement system, the PILS-TOC-IC, was able to provide essential chemical and physical information about fast changes in composition, concentrations and likely sources of the water-soluble fraction of atmospheric aerosol. The concentrations of major watersoluble ions and WSOC were measured by the PILS-TOC-IC system from 25 April to 28 May 2009.

The data of the PILS-TOC-IC setup was compared with the data from the High-Resolution Time-of-Flight Aerosol Mass Spectrometer (HR-ToF-AMS) data measured from 25 April to 8 May 2009. The measured water-soluble particulate organic matter (WSPOM) concentration varied typically from 0.10 to $8.8 \mu \mathrm{g} \mathrm{m}^{-3}$ (on average $1.5 \mu \mathrm{g} \mathrm{m}^{-3}$ ). The WSPOM contributed on average $51 \%$ to particulate organic matter (POM) measured with the AMS. The correlation between the data of all the online measurement devices (AMS, PILS-TOC-IC, semicontinuous EC/OC carbon analyzer and TEOM) was excellent. For sulfate, nitrate and ammonium the correlations between the PILS-TOC-IC and AMS were 0.93, 0.96 and 0.96, respectively. The correlation between WSPOM and POM was also strong $(r=0.88)$. The identified sources of WSPOM were long-range transported biomass burning and secondary organic aerosol (SOA) formation. WSPOM and oxalate produced in biomass burning were clearly correlated with carbon monoxide.
\end{abstract}

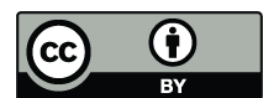

Correspondence to: $\mathrm{H}$. Timonen (hilkka.timonen@fmi.fi)

\section{Introduction}

Atmospheric particles contain carbonaceous material in three different forms, organic carbon (OC), elemental carbon (EC), and carbonate minerals. Typically $20-70 \%$ of atmospheric aerosol mass comprises of organic compounds, and 40-80\% of the organic matter is water-soluble (Saxena and Hildeman, 1995; Jaffrezo et al., 2005). The chemical composition, sources, atmospheric processing, and removal mechanisms of water-soluble organic carbon (WSOC) are inadequately known, yet WSOC is known to have a wide range of poorlyquantified environmental effects ranging from pollution toxicity to visibility degradation (Ten Brink et al., 2004). WSOC in ambient aerosol particles has been shown to take part to largely unknown liquid-phase chemistry of wet aerosol and clouds (Decesari et al., 2001) and to affect the ability of these particles to act as cloud condensation nuclei (Facchini et al., 1999; Kokkola et al., 2006). The analytical procedure to resolve the chemical composition of water-soluble particulate organic matter (WSPOM) has been typically based on a combination of total organic carbon analysis, chromatographic separations and organic functional group analysis (e.g. Decesari et al., 2000, 2007; Ding et al., 2008). These studies have shown that the WSOC fraction is a complex mixture likely composed of aliphatic structures, oxygenated alkyls, carboxylic acids, and aromatic structures. Typically, the individually identified compounds comprise less than $20 \%$ of the total mass of water-soluble compounds (e.g., Yang et al., 2005; Decesari et al., 2006). Recent studies have shown that also humic-like substances (HULIS) are important part of WSOC. HULIS contributes typically for $15-60 \%$ of the fineparticle WSOC (Graber and Rudich, 2006).

Published by Copernicus Publications on behalf of the European Geosciences Union. 
According to the recent results, the identified formation of WSOC is connected with e.g. biomass combustion, secondary aerosol formation, long-range transport and in-cloud processing (Huang et al., 2006; Viana et al., 2007; Saarikoski et al., 2008). Biomass burning and secondary organic aerosol (SOA) formation are considered to be the major sources of WSOC (Miyazaki et al., 2006; Kondo et al., 2007). SOA may originate either from anthropogenic or biogenic sources. Traditionally it has been thought that in urban areas most of the SOA is anthropogenic, however, the recent carbon isotope analysis has revealed that more SOA than expected is formed from biogenic precursors (Szidat et al., 2006, 2009). Also hydrocarbon emissions from vegetation have been shown to greatly influence the number and mass concentrations of aerosols in the boreal region (Tunved et al., 2006). According to Kulmala et al. (2004), the biogenic volatile organic compounds (BVOCs) emitted by forests also enhance the organic aerosol production and growth rate. In addition, the recent results indicate that the organic compounds and their precursor gases evolve in the atmosphere (Jimenez et al., 2009). The aging process in atmosphere leads to the formation of organic aerosol, which is increasingly oxidized, less volatile, more hygroscopic and more water-soluble (Jimenez et al., 2009).

Experimental data on WSOC in ambient air is still scarce especially in the boreal region. The emission, transformation, and transport processes of organic aerosols have timescales ranging from minutes to hours, yet the time-resolution of most of the WSOC data is typically 1-3 days (e.g. Huang et al., 2006; Zhang et al., 2008). This paper describes the new measurement and analyzing system, where one particleinto-liquid sampler (PILS) was coupled to a total organic carbon analyzer (TOC- $\mathrm{V}_{\mathrm{CPH}}$ ) and two ion chromatographs (IC; hereafter the system is called PILS-TOC-IC). PILS-TOCIC was used for simultaneous high time-resolution chemical measurements of the water-soluble fraction (WSOC and ions) of aerosols during one field measurement campaign in spring 2009. PILS-TOC-IC results were compared with the results of High-Resolution Time-of-Flight Aerosol Mass Spectrometer (HR-ToF-AMS), gas analyzers, and meteorological measurements. The online-WSOC measurements have been conducted in the North and South America and in Japan previously, but to our knowledge, these measurements are first online-measurements of WSOC in northern Europe.

\section{Experimental}

\subsection{Measurement site}

The online measurements (PILS-TOC-IC from 25 April to 28 May, AMS from 25 April to 8 May, Semicontinuous EC/OC from 25 April to 1 May) were conducted at the urban background station SMEAR III $\left(60^{\circ} 12^{\prime}, 24^{\circ} 57^{\prime}, 30 \mathrm{~m}\right.$ a.s.l. $)$. The SMEAR III site is situated in the Helsinki Metropolitan Area, on the coast of the Baltic Sea in Southern Finland. The station is located ca. $5 \mathrm{~km}$ northeast from the city centre of Helsinki. It is surrounded by the buildings of the University of Helsinki and the Finnish Meteorological Institute (FMI) on the northeastern side, and by mainly forested area in the west. At a distance of less than $200 \mathrm{~m}$ to the east, there is a major road with heavy traffic (60 000 cars/day).

Long-term measurements of chemical and physical properties of atmospheric aerosols and trace gas concentrations have been conducted at the SMEAR III station since it was established in 2004. Detailed description of the station and long-term measurements conducted on the SMEARIII station is published by Järvi et al. (2009). In Finland the anthropogenic emissions of fine particles and their precursor gases are low. The average annual $\mathrm{PM}_{2.5}$ and $\mathrm{PM}_{10}$ concentrations at the urban background station (in Helsinki 1999-2001) were 9.6 and $18.7 \mu \mathrm{g} \mathrm{m}^{-3}$, respectively (Laakso et al., 2003). Similar results have been later measured by Saarikoski et al. (2007) and Järvi et al. (2009).

\subsection{Meteorological data and gas-phase components}

Local meteorological data were obtained from the Finnish Meteorological Institute Kumpula weather station (Vaisala, Milos 500), next to the SMEAR III station. Temperature was measured using Pt100 (Pentronic Ab) sensor, relative humidity with HMP45D (Vaisala Oyj) sensor, and global radiation with CM11 (Kipp \& Zonen) sensor. To compare with the chemical measurements of this study, one-hour averages were calculated for the meteorological data.

Carbon monoxide (CO) was measured at the SMEAR III station using Horiba APMA 370 analyzer (Horiba, Kyoto, Japan). To establish the potential source areas of the measured aerosol particles, 120-h air mass back trajectories were calculated for the sampling periods using the FLEXTRA model (Stohl and Wotawa, 1995).

\subsection{Particle-into-liquid sampler (PILS)}

The particle-into-liquid sampler has been developed for rapid automated on-line measurement of ambient aerosol bulk composition (Weber et al., 2001; Orsini et al., 2003). The PILS is typically coupled with either ion chromatograph or total organic carbon analyzer (e.g. Kondo et al., 2007; Saarikoski et al., 2008). Examples of the previous measurement campaigns, where PILS has been used, are collected to Table 1 . The campaigns were typically short in duration, from weeks to months and the most of the measurements were conducted in the United States. In addition to the stationary measurements, PILS have been often used in mobile measurements e.g. in an airplane (Sorooshian et al., 2007), in a ship (De Gouw et al., 2008) or in a train (TROICA-9 experiment at the Trans-Siberian railway; Kuokka et al., 2007). In this study, the PILS was coupled with a Shimadzu TOC- $\mathrm{V}_{\mathrm{CPH}}$ analyzer and two Dionex 
Table 1. Main PILS-measurement campaigns reported in the literature.

\begin{tabular}{|c|c|c|c|c|}
\hline Author & Detection & Time-resolution & Time/season & Campaign, Place \\
\hline Orsini et al. (2003) & IC & & 5 weeks & $\begin{array}{l}\text { Field campaign TEXAQS 2000, Houston, } \\
\text { TX }\end{array}$ \\
\hline Broekhuizen et al. (2006) & IC & $15 \mathrm{~min}$ & Several weeks, autumn & $\begin{array}{l}\text { Downtown Toronto, Ontario, } \\
\text { Canada on the University of Toronto } \\
\text { St. George Campus }\end{array}$ \\
\hline Hennigan et al. (2006) & IC & $1.5 \mathrm{~min}$, & 14 days & $\begin{array}{l}\text { NASA INTEX-NA Airplane measure- } \\
\text { ments, centered over the eastern United } \\
\text { States and Canada }\end{array}$ \\
\hline Miyazaki et al. (2006) & WSOC & $6 \min$ & $\begin{array}{l}13 \text { days winter, } 17 \text { days } \\
\text { summer, } 15 \text { days fall. }\end{array}$ & Tokyo urban area \\
\hline Sorooshian et al. (2006) & IC & & 12 flights & $\begin{array}{l}\text { Atmospheric Research on Transport and } \\
\text { Transformation (ICARTT) field cam- } \\
\text { paign, 2004. Airplane measurements over } \\
\text { Ohio and surrounding areas. }\end{array}$ \\
\hline Sullivan et al. (2006) & WSOC & $3 \mathrm{~s}$ & $\begin{array}{l}\text { Large number of flights dur- } \\
\text { ing one month period in } \\
\text { summer }\end{array}$ & $\begin{array}{l}\text { NOAA WP-3D aircraft during the } \\
\text { NEAQS/ITCT 2004, northeastern United } \\
\text { States }\end{array}$ \\
\hline Bae et al. (2007) & IC & $15 \mathrm{~min}$ & $\begin{array}{l}15 \text { days winter, } \\
18 \text { days summer }\end{array}$ & $\begin{array}{l}\text { Urban site in New York City } \\
\text { Rural site in southwestern New York state }\end{array}$ \\
\hline Kondo et al. (2007) & WSOC & $6 \min$ & $\begin{array}{l}13 \text { days winter, } 15 \text { days } \\
\text { summer }\end{array}$ & Tokyo, Japan \\
\hline Kuokka et al. (2007) & $\mathrm{IC}$ & $10 \mathrm{~min}$ & 14 days autumn & Train between Moscow and Vladivostok \\
\hline Peltier et al. (2007) & WSOC & & 5 months & Atlanta, GA, and Riverside, CA. \\
\hline Sorooshian et al. (2007) & IC & $5 \mathrm{~min}$ & 22 flights, 976 samples & $\begin{array}{l}\text { GoMACCS, airplane measurements } \\
\text { above East Texas and the Gulf of Mexico }\end{array}$ \\
\hline Weber et al. (2007) & WSOC & $3 \mathrm{~s}$ & $\begin{array}{l}\text { Many } \\
\text { flights }+ \text { ground } \\
\text { based measurement cam- } \\
\text { paign during summer } \\
2004\end{array}$ & $\begin{array}{l}\text { Atlanta, GA + flights above over a large } \\
\text { area of northern Georgia }\end{array}$ \\
\hline De Gouw et al. (2008) & WSOC & $1 \mathrm{~min}$ & $\begin{array}{l}1 \text { month cruise }+18 \text { flights } \\
\text { during a month in summer }\end{array}$ & $\begin{array}{l}\text { NEAQS-ITCT 2004, } 18 \text { research aircraft } \\
\text { (WP-3D) flights above eastern US and } \\
\text { the NOAA research ship cruising at Mas- } \\
\text { sachusetts and New Hampshire coast }\end{array}$ \\
\hline Hennigan et al. (2008a, b) & WSOC & $6 \min$ & 4 months & Atlanta \\
\hline Hennigan et al. (2008c) & WSOC, IC & & 24 days & $\begin{array}{l}\text { MILAGRO field campaign in Mexico } \\
\text { City }\end{array}$ \\
\hline Saarikoski et al. (2008) & $\mathrm{IC}$ & $15 \mathrm{~min}$ & 1 year (2006-2007) & SMEAR III station Helsinki, Finland \\
\hline Miyazaki et al. (2009) & WSOC & $6 \min$ & 26 days & Guangzhou, China \\
\hline Miyazaki et al. (2009) & WSOC & $6 \min$ & & $\begin{array}{l}\text { PRIDE-PRD campaign, rural site Pearl } \\
\text { River Delta region, China }\end{array}$ \\
\hline Partshitsev et al. (2009) & GC-MS & $2 \mathrm{~h}$ & 6 days & SMEAR II station at Hyytiälä, Finland \\
\hline
\end{tabular}

ICS-2000 ion chromatographs to enable high time-resolution (WSOC $6 \mathrm{~min}$, ions $15 \mathrm{~min}$ ) measurements of water-soluble organic carbon and water-soluble ions. PILS-TOC-IC measurements were conducted from 25 April to 28 May 2010.

\subsubsection{Sampling line}

A cyclone (sharp cut cyclone SCC 1.829, BGI Inc. US) was used on the top of the sampling line to cut off supermicron particles (particle aerodynamic diameter $>1 \mu \mathrm{m}$ ). After the cyclone, the sample flow $\left(111 \mathrm{~min}^{-1}\right)$ was directed to two denuders. A parallel plate carbon filter denuder (Sunset Laboratory Inc., Portland, OR) and an annular denuder (URG2000, $30 \times 242 \mathrm{~mm}$, Chapel Hill, NC) coated with $\mathrm{H}_{3} \mathrm{PO}_{4}$ were used to remove gaseous organic components and ammonia from the sample. After the denuders, the line was divided into a sample-line and a blank-line. The sampleline fed the airflow directly to the PILS. In the blank-line the airflow was directed first through a PTFE filter (type $\mathrm{FS}$, diameter $47 \mathrm{~mm}$, pore size $3 \mu \mathrm{m}$, Millipore, Ireland) and 


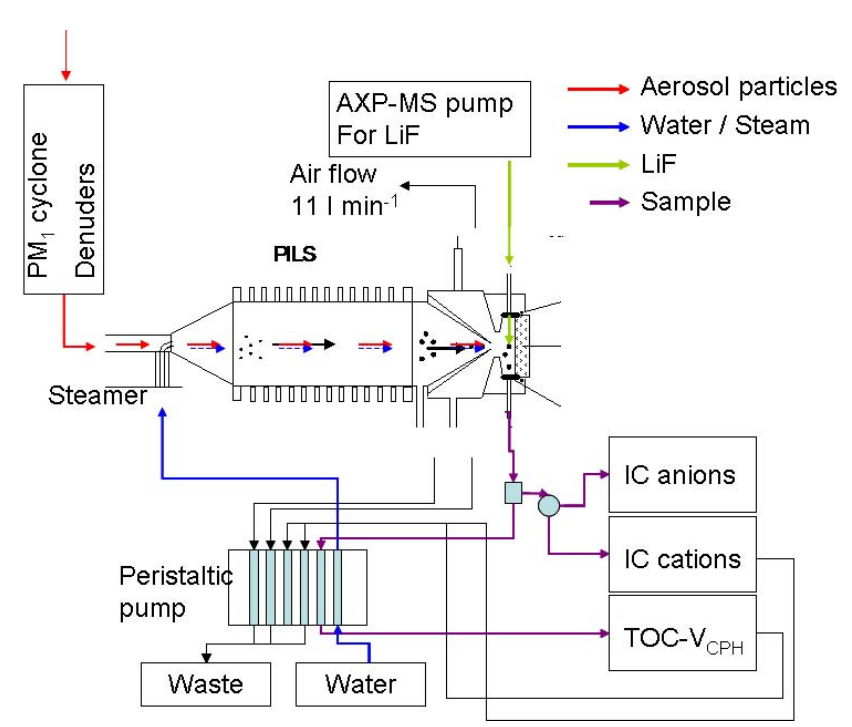

Fig. 1. PILS-TOC-IC measurement device. Arrows represent the flow of the sample and liquids within the system.

subsequently fed to the PILS. When the blank values were measured, a valve was used to force the airflow through a PTFE filter. The blank value was measured for approximately $1 \mathrm{~h}$ every day during the week days to evaluate the influence impurities in solvents and system as well as the breakthrough of gases from denuders to the results.

\subsubsection{Coupling the instruments to the PILS}

In this study, a liquid sample from one PILS (Metrohm Peak Inc) was shared by the Shimadzu TOC- $\mathrm{V}_{\mathrm{CPH}}$ analyzer and two Dionex ICS-2000 ion chromatographs to enable simultaneous high time-resolution measurements of water-soluble organic carbon and water-soluble ions. Figure 1 represents the designed PILS-TOC-IC system. The design and the operating principle of the PILS have been described in detail by Orsini et al. (2003). Shortly, aerosol particles are mixed with water-vapor and after cooling they grow into droplets inside a conical-shaped cavity. After the cavity, the droplets go through a nozzle and are impacted onto a quartz glass impaction plate. The impaction plate is washed off with a steady stream of the transport liquid containing internal standard (lithium fluoride, LiF). During collection, liquid that has been condensed onto aerosol particles and a small amount of water condensing out of the saturated air to the quartz impaction surface dilutes the transport liquid. Based on the $\mathrm{LiF}$ concentration prior and after the PILS, this dilution is taken into account and the aerosol concentration can be accurately calculated. Since the dilution factor calculation is based on the IC data, it is usually estimated for the PILSTOC measurements. In the PILS-TOC-IC system developed in this study, the dilution factor for the WSOC samples can be accurately determined from the simultaneous IC data, since the same sample is fed for both instruments. Sudden increases in the dilution factor can also be used to detect the reduced liquid flows e.g. due to the blocked capillary tubes. By using one PILS for both devices instead of two PILS, the amount of liquid consumed was reduced and also the amount of cleaning (e.g. quartz impaction surface) and maintenance work (e.g. replacing dirty and blocked capillary tubes) was reduced. After impaction to the quartz surface, the sampleliquid is delivered into a debubbler to remove air and to divide the liquid-flow into two separate lines.

Two liquid pumps were used to control the liquid flows in the PILS-TOC-IC system, an 8-channel peristaltic pump (Watson Marlow, 205S, USA) and a piston pump (AXPMS, Dionex, USA). The peristaltic pump was used to feed $1.25 \mathrm{ml} \mathrm{min}^{-1}$ of water for the steamer and to deliver the sample from the debubbler to the TOC- $\mathrm{V}_{\mathrm{CPH}}$ $\left(0.22 \mathrm{ml} \mathrm{min}^{-1}\right)$ and the ion chromatographs $\left(0.1 \mathrm{ml} \mathrm{min}^{-1}\right.$ for each). The LiF-flow $\left(0.37 \mathrm{ml} \mathrm{min}^{-1}\right)$ was controlled with a separate AXP-MS pump to maintain the flow as stable as possible.

\subsubsection{Online chemical analysis}

The debubbler divided the PILS-sample into two equal fractions. One fraction was fed through an inline PTFE filter to remove the water-insoluble carbonaceous particles from the sample and then collected to a sealed glass bottle for the subsequent WSOC analysis. WSOC was analyzed by a total-organic carbon analyzer (TOC- $\mathrm{V}_{\mathrm{CPH}}$, Shimadzu). The non-purgeable organic carbon (NPOC) method was used because it was necessary to remove carbonate carbon and carbon dioxide from the samples before the measurements. The sample that has been fed from the PILS into a bottle was automatically drawn through a tube to a syringe of the TOC$\mathrm{V}_{\mathrm{CPH}}$. To avoid mixing between the consecutive samples, the sample volume was adjusted so that the sample bottle was empty between the samples. In the syringe, the sample was acidified and bubbled for $5.5 \mathrm{~min}$ with helium (grade 5.0) to remove carbonate carbon and carbon dioxide, and then injected into an oven. In the oven, carbonaceous material of the sample was catalytically (platinum on quartz wool high sensitivity catalyst) oxidized to $\mathrm{CO}_{2}$ at $680^{\circ} \mathrm{C}$ and the produced $\mathrm{CO}_{2}$ detected by a sensitive non-dispersive infrared (NDIR) detector. The estimated error of the WSOC measurement is $15 \%$ for atmospheric concentrations $<2 \mu \mathrm{g} \mathrm{m}^{-3}$ and $10 \%$ for concentrations $>2 \mu \mathrm{g} \mathrm{m}^{-3}$. The limit of quantification for the TOC- $\mathrm{V}_{\mathrm{CPH}}$ is $4 \mu \mathrm{g} 1^{-1}$, which equals to an air concentration $0.15 \mu \mathrm{g} \mathrm{m}^{-3}$. The time-resolution of the measurement was adjusted to six minutes to collect large enough sample for the TOC- $\mathrm{V}_{\mathrm{CPH}}$ analyzer. In order to estimate the amount of particulate organic matter (WSPOM), the WSOC concentrations were multiplied by the estimated average molecular weight per carbon weight in aerosols. For simplicity, the constant ratio of 1.6 was used in this work, based on calculations published by Turpin and Lim (2001) and Saarnio et 
al. (2010), but the ratio may vary and likely be higher e.g. depending on the aerosol aging.

The other fraction of the collected PILS sample was further split to two equal fractions by a simple t-shape splitter and fed continuously to the sample loops $(1 \mathrm{ml})$ of the two ion chromatographs to measure anions and cations. The time-resolution of ion measurements was $15 \mathrm{~min}$. The ions $\left(\mathrm{Na}^{+}, \mathrm{NH}_{4}^{+}, \mathrm{K}^{+}, \mathrm{Mg}^{2+}, \mathrm{Ca}^{2+}, \mathrm{Cl}^{-}, \mathrm{NO}_{3}^{-}, \mathrm{SO}_{4}^{2-}\right.$, oxalate $)$ were analyzed using the Dionex ICS-2000 (Dionex, Sunnyvale, USA) ion chromatographs. The ion chromatographs had the AG11/CG12A guard columns, AS17/CS12A analytical columns and ASRS/CSRS ultra II suppressors for anion and cation analyzes, respectively. $\mathrm{KOH}$ solution, with concentration gradient from 2 to $35 \mathrm{mmol} \mathrm{l}^{-1}$, was used as the eluent for anions. For cations the eluent was $20 \mathrm{mmoll}^{-1}$ methanesulphonic acid. The uncertainty of the IC analysis was of the order of $10-15 \%$ for all analyzed ions. The quantification limit for major ions was $2.5 \mathrm{ng} \mathrm{ml}^{-1}$, which equals to the air concentration of $0.1 \mu \mathrm{g} \mathrm{m}^{-3}$.

Blank values were measured for the PILS-TOC-IC system by directing the air flow through a PTFE filter prior to the PILS. The blank values measured for ions were typically very low compared to the liquid containing dissolved ions from the aerosol particles. For WSOC the blank values were larger, typically $1.3 \pm 0.5 \mu \mathrm{g} \mathrm{m}^{-3}$. The blank values of WSOC were subtracted from the corresponding results. The blank concentrations were assumed to be constant between the consecutive background measurements.

\subsection{Aerodyne High-Resolution Time-of-Flight Aerosol Mass Spectrometer}

The Aerodyne High-Resolution Time-of-Flight Aerosol Mass Spectrometer (HR-ToF-AMS, Aerodyne Research Inc., USA), previously described by DeCarlo et al. (2006), was used to determine the concentrations of major fine particulate matter species: POM, sulfate, nitrate, chloride, and ammonium from 25 April to 8 May 2010. The HR-ToF-AMS consists of a particle sampling inlet, a particle sizing chamber, and a particle composition detection section. Aerosol particles are sampled through an aerodynamic lens, forming a narrow particle beam that is transmitted into the detection chamber where the non-refractory species are flashvaporized upon impact on a hot surface $\left(600^{\circ} \mathrm{C}\right)$ under high vacuum. The composition is subsequently analyzed via electron impact ionization $(70 \mathrm{eV})$ by the high resolution timeof-flight mass spectrometer. During the measurements, the AMS was alternating between V-mode and W-mode. Vmode is a single-reflection configuration with higher sensitivity and lower resolving power (unit mass resolution) and the W-mode is a two-reflectron configuration with higher resolving power but lower sensitivity (DeCarlo et al., 2006). In this study five minute average results of the unit mass resolution data from V-mode was used. The IGOR 6.11 (Wavemetrics, Lake Oswego, OR) and Squirrel 1.47 (Sueper, 2009) were used to analyze the AMS data. A collection efficiency of 0.5 was used for the data.

\subsection{TOA}

A semicontinuous EC/OC carbon analyzer (TOA; Sunset Laboratory Inc., Oregon) was used to continuously measure concentrations of organic and elemental carbon (OC and EC) with two hours time resolution. The method is described in detail by Saarikoski et al. (2008). Shortly, a cyclone with cutoff at $1 \mu \mathrm{m}$ was used to remove the coarse particles and a parallel plate carbon denuder (Sunset laboratory Inc., Portland, OR) was used to remove the organic gaseous compounds from the sample air. In the thermal method helium with two temperature steps: $600^{\circ} \mathrm{C}(80 \mathrm{~s})$ and $840^{\circ} \mathrm{C}(90 \mathrm{~s})$ was used to determine $\mathrm{OC}$ and helium-oxygen mixture with three temperature steps: $550^{\circ} \mathrm{C}(30 \mathrm{~s}), 650^{\circ} \mathrm{C}(45 \mathrm{~s})$ and $850{ }^{\circ} \mathrm{C}(90 \mathrm{~s})$ was used to determine EC. Charring of OC was corrected optically using the data obtained from the tuned diode laser. The instrumental blank was analyzed daily at 03:00 for three minutes. The blank values were subtracted from the results. The uncertainty of OC and EC results was estimated to be 20\% (Arhami et al., 2006; Saarikoski et al., 2008; Saarnio et al., 2010).

\subsection{TEOM}

A tapered element oscillating microbalance (TEOM, model 1400ab) was used to measure the $\mathrm{PM}_{1.3}$ total mass continuously. A PM 1.3 virtual impactor (VI; Loo and Cork, 1988) was used to cut off the supermicron particles. TEOM collects the sample on the filter placed on the oscillating element. The mass collected on the filter changes the oscillating resonance frequency. The changes in the oscillating resonance frequency are recorded and converted to mass. The results of TEOM are not corrected for evaporation of semivolatile aerosol compounds. The uncertainty of the TEOM was estimated to be $10 \%$.

\section{Results and discussion}

\subsection{The origin of air masses}

Based on satellite observations deploying MODIS sensor on board of NASA EOS Terra satellite and on the backward trajectories of air masses, smoke from the major forest fire areas in the southern and eastern Europe were transported to the measurement site from 26 April to 29 April 2009. For that period the $\mathrm{PM}_{1.3}$ mass concentrations were high (10$20 \mu \mathrm{g} \mathrm{m}^{-3}$ ) and also elevated sulfate, ammonium, and nitrate concentrations were measured (Fig. 2). The AMS mass to charge ratios $m / z, 60$ and 73, known as biomass burning tracers (Lanz et al., 2007), were elevated (not shown), indicating that the aerosols were originating from biomass burning. Also potassium can be used as a combustion tracer 


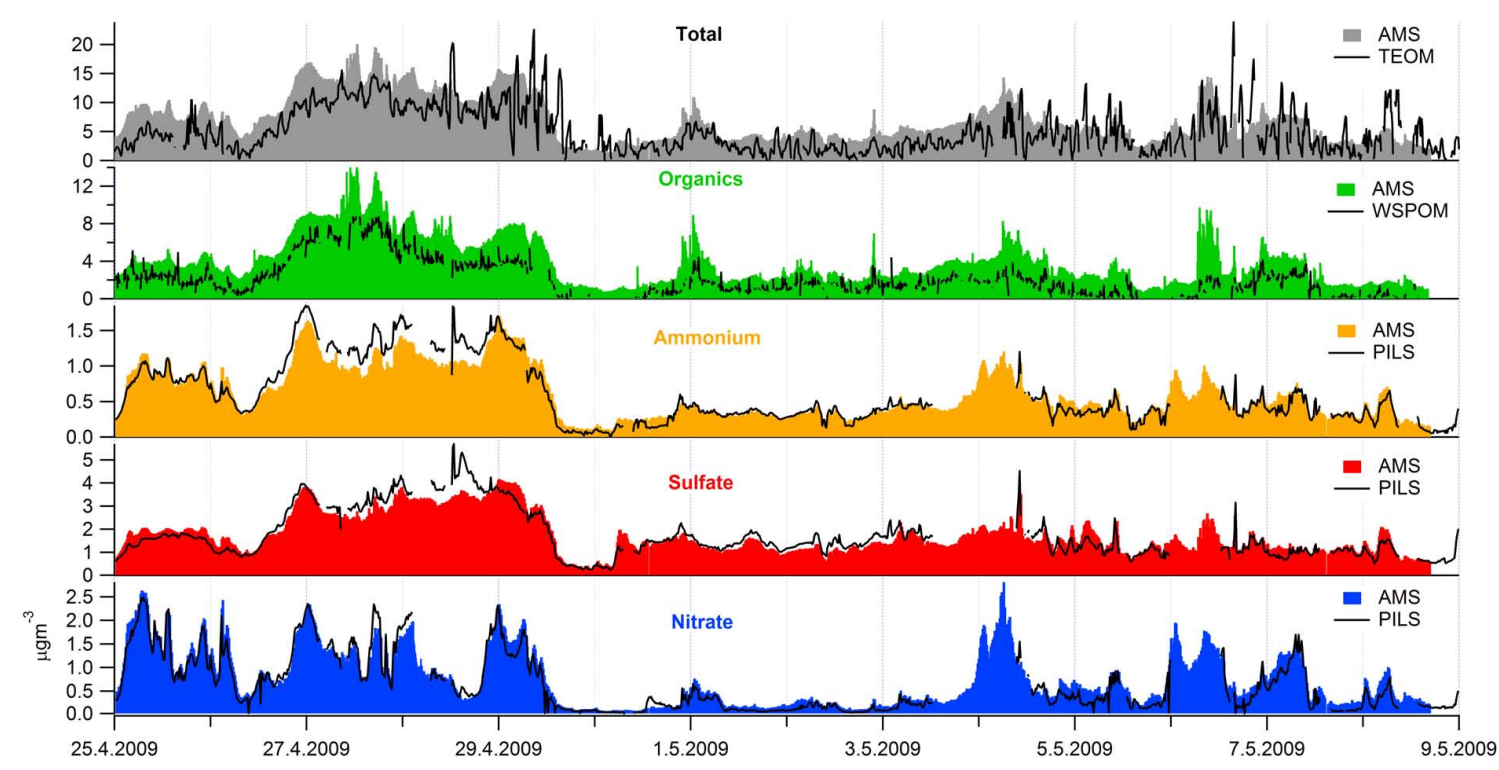

Fig. 2. Concentrations of major ions and WSPOM (using conversion factor 1.6 to convert WSOC to WSPOM) measured by PILS-TOC-IC and AMS from 25 April to 8 May 2009. PILS-TOC-IC (ions, WSPOM) and TEOM (total mass) results are marked with the black line. AMS results are marked with colors (blue $=$ nitrate, red $=$ sulfate, yellow $=$ ammonium, green $=$ total organics, grey $=$ total mass i.e. sum of ions and organics).

(e.g., Watson et al., 1994). Elevated potassium concentrations $\left(0.3-0.6 \mu \mathrm{g} \mathrm{m}^{-3}\right)$ were measured with the PILS-TOCIC during the biomass burning episode (not shown). However, high concentrations of secondary ions (sulfate, nitrate and ammonium) in inorganic aerosol composition suggested that biomass burning emissions were mixed with other anthropogenic sources during the transport. Similar long-range transported biomass burning episodes are detected in Finland almost every spring and summer (Sillanpää et al., 2005; Saarikoski et al., 2007; Saarnio et al., 2010).

For the rest of the measurement period (25-26 April and 29 April-28 May) the trajectories showed that air masses came over forested clean areas either from north or west. During that period the $\mathrm{PM}_{1.3}$ mass concentration was typically below $10 \mu \mathrm{g} \mathrm{m}^{-3}$ and the concentrations of sulfate, ammonium and nitrate varied from moderate to low (Fig. 2).

\subsection{Water-soluble particulate organic matter and ion concentrations}

The concentrations of major water-soluble ions and WSOC were measured by the PILS-TOC-IC system between 25 April and 28 May 2009. The WSPOM concentration (using conversion factor 1.6 to convert WSOC to WSPOM) varied from 0.10 to $8.8 \mu \mathrm{g} \mathrm{m}^{-3}$ (Fig. 2). On average, the WSPOM concentration was $1.5 \mu \mathrm{g} \mathrm{m}^{-3}$. Sulfate was the most abundant ion with an average concentration of $1.5 \mu \mathrm{g} \mathrm{m}^{-3}$, but with a maxima reaching up to $5.8 \mu \mathrm{g} \mathrm{m}^{-3}$. The ammonium concentrations ranged from below the limit of quantification $\left(0.1 \mu \mathrm{g} \mathrm{m}^{-3}\right)$ to $5.0 \mu \mathrm{g} \mathrm{m}^{-3}$. The concentration of nitrate during the study was rising up to $2.9 \mu \mathrm{g} \mathrm{m}^{-3}$. During the biomass burning episode, elevated WSPOM values, as high as $8.8 \mu \mathrm{g} \mathrm{m}^{-3}$, were measured. The ion concentrations were also elevated during the biomass burning episode. For the episode period the average sulfate, ammonium, and nitrate concentrations were $3.7,1.4$ and $2.2 \mu \mathrm{g} \mathrm{m}^{-3}$, respectively.

The HR-ToF-AMS measurements were conducted from 25 April to 8 May 2009. For major ions (sulfate, nitrate and ammonium), the time-series measured by the PILSTOC-IC and the HR-ToF-AMS followed each other very closely (Fig. 2). The five-minute average POM concentrations measured with the AMS varied from 0.2 to $14 \mu \mathrm{g} \mathrm{m}^{-3}$ (during biomass burning episode $4.0-14 \mu \mathrm{g} \mathrm{m}^{-3}$ ). The WSPOM (PILS-TOC-IC) to POM (AMS)-ratios were calculated. On average $51 \%$ of POM consisted of WSPOM. During the biomass burning episode, the WSPOM/POM-ratio was higher, being $69 \%$ on average. The major ions, sulfate, ammonium, and nitrate accounted for 30\%, 10\% and 9\% of the total mass, respectively.

The results of the different high-resolution online instruments were compared. All PILS-TOC-IC results correlated closely with the AMS results. For sulfate, nitrate and ammonium the correlations between the PILS-TOC-IC and AMS were $0.93,0.96$ and 0.96 , respectively. The total mass (sum of ions and organics, not including EC) calculated from the AMS data was compared to the total mass measured with TEOM $\left(\mathrm{PM}_{1.3}\right.$, including EC, not corrected for evaporation of semivolatile aerosol compounds). The time-series of total mass from AMS and TEOM has clearly a similar temporal pattern (Fig. 2). The POM results from the semicontinuous 


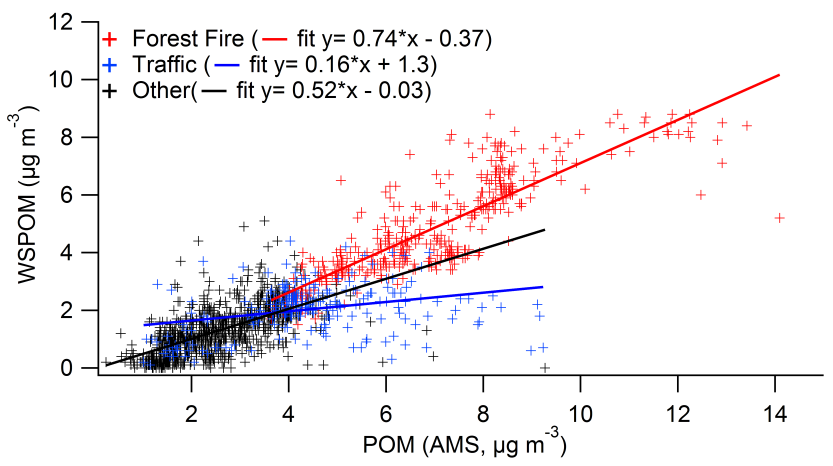

Fig. 3. WSPOM versus POM for different sources of WSPOM. The equations $(y=k x+b)$ of fitted curves represented after each legend.

EC/OC-analyzer were compared to POM measured by the AMS. Unfortunately the EC/OC-analyzer oven was broken down during the campaign, and therefore only the results of first week (25 April to 1 May) were available for the comparison. For the first week the correlation was very good $(r=0.88)$.

A correlation was also observed between POM measured by the AMS and WSPOM measured by the PILS-TOC-IC system $(R=0.66)$, indicating that the WSPOM is major component of POM. This correlation was further studied by dividing the WSPOM data into three subsets on the basis of the AMS data and the air mass back trajectories: 1) samples influenced by biomass burning (the period from 26 April, 12:00 to 29 April, 11:00, $\mathrm{m} / \mathrm{z}, 60$ elevated, the trajectories show that the particles originate from wild fire areas), 2) samples influenced by traffic (three separate episodes, from 30 April, 18:00 to 1 May, 07:00, 4 May, 05:00-13:00, from 6 May, 07:00 to 7 May, 11:00, when the $\mathrm{m} / z 57$ was elevated above $\left.0.2 \mu \mathrm{g} \mathrm{m}^{-3}\right)$, 3) other samples. Subset three "other samples" includes all the samples that did not fit on the previous two subsets i.e. they have other sources than the biomass burning episode and traffic. For biomass burning samples, WSPOM and POM were highly correlated (Fig. 3; $r=0.85$, slope 0.74 ) but for the periods influenced by traffic, WSPOM didn't correlate with POM ( $r=0.31$, slope 0.16$)$. The different slope for traffic sources is probably explained by the fact that traffic emissions are more local, fresh and water-insoluble, when compared to aged water-soluble longrange transported aerosols. Also it is likely that traffic emissions are partly primary particles due to incomplete combustion of fuel in engines. For the subset three, other samples, there was a correlation between WSPOM and POM $(r=0.66$, slope 0.52 ), however, the correlation was weaker than for biomass burning.

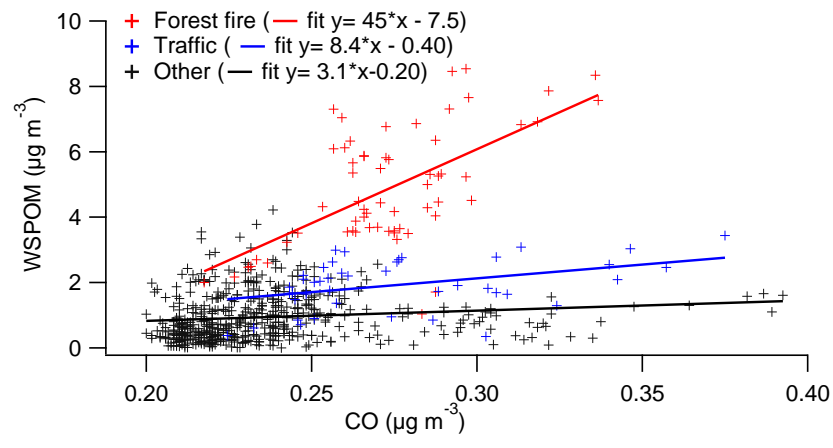

Fig. 4. Concentration of water-soluble particulate organic matter versus carbon monoxide concentration for different sources of WSPOM. The equations $(y=k x+b)$ of fitted curves represented after each legend.

\subsection{Correlation of WSPOM with $\mathrm{CO}$ and oxalate}

Carbon monoxide is often considered as a tracer for urban pollution caused by traffic, but is also formed in incomplete burning of biomass (Ovadnevaite et al., 2006). Clear correlations between CO and WSPOM have been reported in many studies (e.g. Sullivan et al., 2006; de Gouw et al., 2008). Those studies have been made in places where the urban pollution affects aerosol concentrations significantly. Finland is situated in the boreal region, where biogenic emissions are large (Hakola et al., 2003) and the $\mathrm{PM}_{1}$ concentration is typically low (Laakso et al., 2003). During the measurement period of this study, the total mass concentration $\left(\mathrm{PM}_{1.3}\right.$, measured by the TEOM) was typically below $10 \mu \mathrm{g} \mathrm{m}^{-3}$. Elevated concentrations (10-20 $\mu \mathrm{g} \mathrm{m}^{-3}$ ) were measured only when the smoke from forest fires were drifted from the Eastern Europe. To examine the correlation between $\mathrm{CO}$ and WSPOM, the measured WSPOM values were divided into same subsets as before: 1) samples influenced by the longrange transported biomass burning smoke, 2) samples influenced by traffic, 3 ) the other samples. The WSOC versus $\mathrm{CO}$ scatter plot (Fig. 4) clearly shows that during the biomass burning episodes WSPOM emissions were increasing with increasing $\mathrm{CO}(r=0.85$, slope 45$)$, whereas during traffic episodes (slope $=0.16$ ) the amount of WSPOM was not correlated with $\mathrm{CO}(r=0.31$, slope 0.16$)$. This suggests that primary WSPOM is produced in biomass burning. The other samples $(r=0.12$, slope 3.13$)$ had no clear correlation with $\mathrm{CO}$.

Oxalate is a water-soluble acid, contributing typically $1-$ $3 \%$ of the fine mode WSPOM. Oxalate has various sources such as vehicle emissions, biomass burning, in-cloud processing and atmospheric oxidation of VOCs (Huang et al., 2006; Hsieh et al., 2007). In this study oxalate constituted on average $3.8 \%$ of WSPOM. Typically oxalate concentrations were below quantification limit, $0.1 \mu \mathrm{g} \mathrm{m}^{-3}$, but during the forest fire episode elevated concentrations $(0.1-$ $0.3 \mu \mathrm{g} \mathrm{m}^{-3}$ ) were measured (Fig. 5). The results that were 


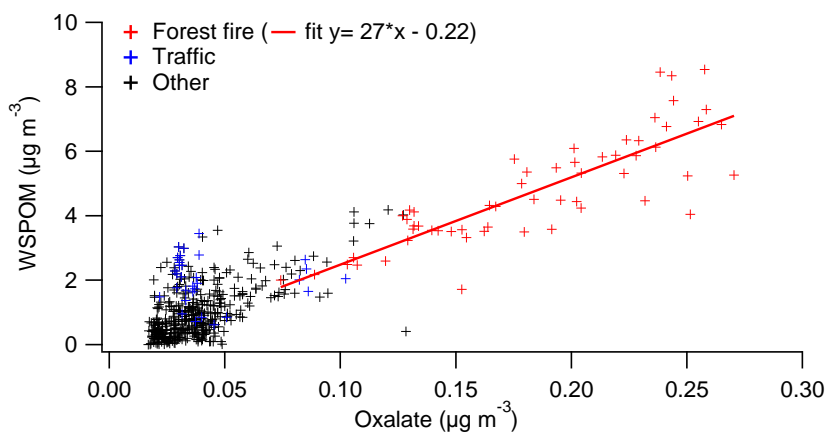

Fig. 5. The concentration of water-soluble particulate organic matter versus concentration of oxalate for different sources of WSPOM. The equation $(y=k x+b)$ of fitted curve for samples collected during the forest fire episode is represented after the legend. For the other periods the concentrations are below quantification limit and the results are plotted to figure only for qualitative purposes.

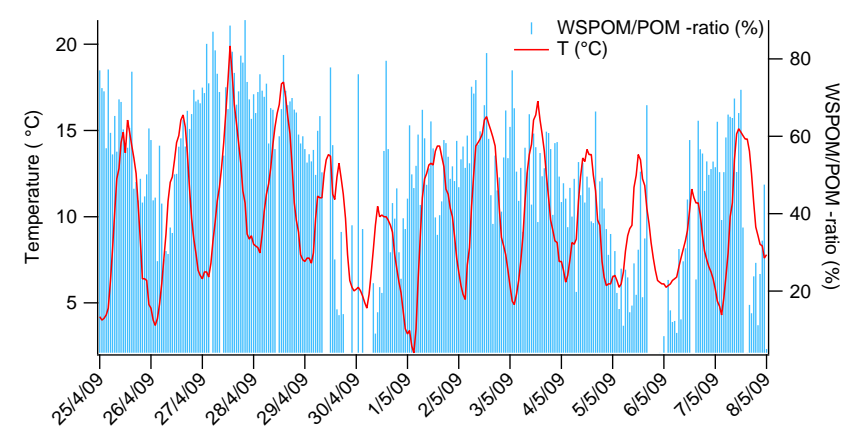

Fig. 6. Time-series of WSPOM/POM-ratio and temperature from 25 April to 8 May 2009.

below quantification limit have been plotted to Fig. 5 for qualitative purpose to show the difference between forest fire episode and the rest of the measurement period. However, the error in the concentration measurements close or below quantification limit can be large. The oxalate concentrations during the forest fire episode were clearly correlated with WSPOM (Fig. 5, $r=0.82$, slope 27). Also, a strong correlation was observed between oxalate and $\mathrm{CO}(r=0.83)$ during the biomass burning episode, suggesting that oxalate was produced in the biomass burning process or it was subsequently formed after the burning by secondary formation. Oxalate concentration was not correlated with the concentrations of secondary inorganic ions (sulphate, ammonium or nitrate), suggesting that the source regions of the oxalate and inorganic secondary ions are different.

\subsection{Secondary organic aerosol}

In studies made in Tokyo (Japan) the secondary organic aerosol formation was estimated to be the dominating source of WSOC in the absence of biomass burning emissions (Fuzzi et al., 2006; Miyazaki et al., 2006; Kondo et al.,

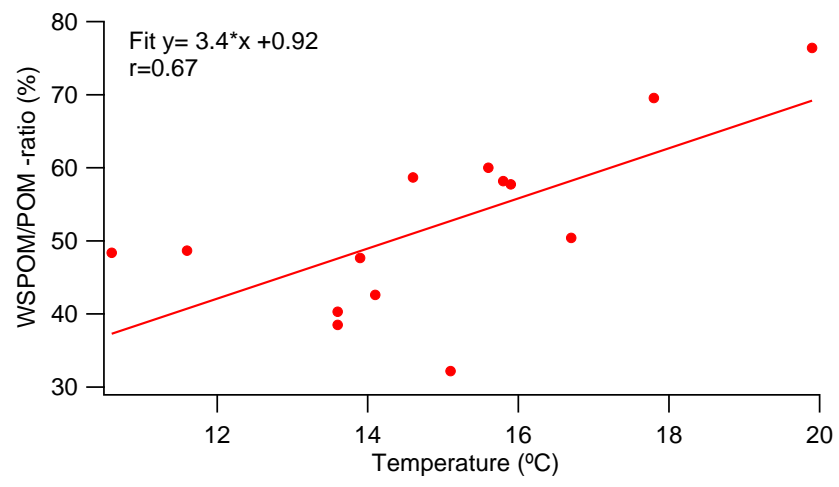

Fig. 7. Average WSPOM/POM-ratios in afternoon (12:00 to 16:00) vs. daily maximum temperature between 25 April, and 8 May 2009.

2007). Meteorological conditions such as temperature and relative humidity have been found to have an effect on the SOA formation and thus on WSOC formation. Warren et al. (2009) noticed that higher temperature clearly increases the total SOA formation in the chamber experiments made with cyclohexene and $\alpha$-pinene. Hennigan et al. (2008a) reported that WSOC gas/particle partitioning shows a strong RH dependence that was attributed to particulate liquid water. At elevated RH levels (>70\%) they observed an increase in WSOC partitioning to the particle phase. Studies in remote regions (Claeys et al., 2004; Tunved et al., 2006) have proved the importance of biogenic VOCs as the POM precursors.

In this study, the concentrations of WSOC did not directly correlate with temperature, relative humidity, or global radiation. However, the WSPOM/POM -ratio was found to have a similar temporal pattern with the maximum temperature of the day (Fig. 6). The higher the maximum temperature of the day was, the higher was the WSPOM/POM-ratio. The relative humidity or the global radiation did not have the same temporal pattern with the WSPOM/POM-ratio. To further investigate the effect of temperature on WSOC, the PILSTOC-IC data was divided into samples measured in daytime (1-h average WSOC results from 06:00 to 18:00) and in night-time (1-h average WSOC results from 18:00 to 06:00). In night-time, there was no correlation between temperature and the WSOC concentrations or the WSPOM/POMratio. In daytime no correlation was found between the WSOC concentration and temperature. However, the average WSPOM/POM-ratio in afternoon (from 12:00 to 16:00) and maximum temperature of the day had a certain correlation (Fig. 7, $r=0.67$, slope $=3.4$ ). Similar behavior has been observed in some other studies also. Jaffrezo et al. (2005) found out that the higher WSOC/OC-ratios $(>60 \%)$ are observed when the temperatures are above $5{ }^{\circ} \mathrm{C}$. Also Hennigan et al. (2008a) observed that the daily median water-soluble organic matter concentrations were increasing linearly with the increasing temperature. 
Based on our data it was impossible to conclude whether the observed temperature dependency in WSPOM/POMratio was actually caused by the temperature or some other variable (like changes in boundary layer height, other meteorological variables than temperature or differences in aerosol chemical aging) varying simultaneously with the temperature or even causing the change in WSPOM and the temperature. Anyhow, the SOA formation from biogenic volatile organic compounds emitted by the boreal forests is one possible explanation for the results. The biogenic volatile organic compound (BVOC) emissions by boreal forests typically depend on temperature and light (Kulmala et al., 2004, and references therein). The trajectories showed that during the campaign (25 April to 28 May 2009, excluding the forest fire episode during 26-29 April) aerosols came over the forested areas in the west and north. The poor correlation of WSOC with CO and sulfate suggested that neither the anthropogenic secondary aerosol formation nor the long-range transport was the major source during that time.

\section{Summary and conclusions}

In this work, a new method for the online measurement of water-soluble fraction of ambient aerosols was developed by combining a PILS with TOC- $\mathrm{V}_{\mathrm{CPH}}$ and two IC analyzers. The concentrations of water-soluble organic carbon and ions were measured for a month (25 April to 28 May 2009) in southern Finland with the PILS-TOC-IC. The high timeresolution (6 min and $15 \mathrm{~min}$, respectively) of the measurements provided data that could follow the rapid changes in WSOC and ion concentrations. Also, by coupling one PILS simultaneously to two instruments, the amount of work was reduced and the reliability of measurements was increased. The high time-resolution data of WSPOM enables observation of diurnal variations and comparison of the data with gas-phase compounds typically measured continuously as well as with the meteorological data. Additionally an advantage of high-resolution data was that WSPOM can be connected to the potential sources. Moreover, the online sample analyzes minimized the contamination risk (common in handling and storage of samples in offline methods) and the sampling artifacts (like evaporation and absorption of organic gases).

The PILS-TOC-IC data was compared to the AMS data measured between 25 April and 8 May 2009. For sulfate, nitrate and ammonium, the correlations between the PILS-TOC-IC and AMS were 0.93, 096 and 0.96, respectively. Also POM (AMS) and WSPOM (PILS-TOC-IC) results were correlated $(r=0.66)$. The good correlation between the two different instruments shows that both methods can provide high time-resolved, quantitative data. The results of AMS were also strongly correlated with the results of TEOM and semicontinuous EC/OC carbon analyzer.
Biomass burning was pointed out as one of the major individual sources of WSPOM. WSPOM and oxalate produced by biomass burning had a clear correlation with $\mathrm{CO}$, indicating that primary WSOC is produced in biomass burning. More indirectly it was suggested on the basis of this study that biogenic SOA formation might also generate watersoluble organic carbon. The high time-resolution data of the AMS and the PILS-TOC-IC system may provide unique insight into the sources and behavior of water-soluble organic carbon and ions. In addition, the high time-resolution data enabled one to study diurnal changes and the correlations between the meteorological data and WSPOM. Although the measurements covered only quite short period representing late spring and early summer, the study showed that realtime observations may be valuable in tracking sources and formation routes of atmospheric aerosols.

Acknowledgements. Financial support from the Graduate School in Physics, Chemistry, Biology and Meteorology of Atmospheric Composition and Climate Change (University of Helsinki), European Union (EUCAARI, Contract No: 036833-2), Helsinki Energy and the Ministry of Transport and Communications Finland (project number 20117) is gratefully acknowledged. The research was also supported by the Academy of Finland Center of Excellence program (project number 1118615).

Edited by: P. Laj

\section{References}

Arhami, M., Kuhn, T., Fine, P. M., Delfino, R. J., and Sioutas, C.: Effects of Sampling Artifacts and Operating Parameters on the Performance of a semicontinuous Particulate Elemental Carbon/Organic Carbon Monitor, Environ. Sci. Technol., 40, 945954, 2006.

Bae, M.-S., Schwab, J. J., Zhang, Q., Hogrefe, O., Demerjian, K. L., Weimer, S., Rhoads, K., Orsini, D., Venkatachari, P., and Hopke, P. K.: Interference of organic signals in highly time resolved nitrate measurements by low mass resolution aerosol mass spectrometry, J. Geophys. Res., 112, D22305, doi:10.1029/2007JD008614, 2007.

Broekhuizen, K., Chang, R.Y.-W., Leaitch, W. R., Li, S.-M., and Abbatt, J. P. D.: Closure between measured and modeled cloud condensation nuclei $(\mathrm{CCN})$ using size-resolved aerosol compositions in downtown Toronto, Atmos. Chem. Phys., 6, 2513-2524, doi:10.5194/acp-6-2513-2006, 2006.

Claeys, M., Graham, B., Vas, G., Wang, W., Vermeylen, R., Pashynska, V., Cafmeyer, J., Guyon, P., Andreae, M. O., Artaxo, P., and Maenhaut, W.: Formation of secondary organic aerosols through photooxidation of isoprene, Science, 303, 1173-1176, doi:10.1126/science.1092805, 2004.

DeCarlo, P. F., Kimmel, J. R., Trimborn, A., Northway, M., Jayne, J. T., Aiken, A. C., Gonin, M., Fuhrer, K., Horvath, T., Docherty, K. S., Worsnop, D. R., and Jimenez, J. L.: Field-Deployable, HighResolution, Time-of-Flight Aerosol Mass Spectrometer, Anal. Chem., 78, 8281-8289, 2006.

Decesari, S., Facchini, M. C., Fuzzi, S., and Tagliavini, E.: Characterization of water-soluble organic compounds in atmospheric 
aerosols: a new approach, J. Geophys. Res., 105, 1481-1489, 2000.

Decesari, S., Facchini, M. C., Matta, E., Lettini, F., Mircea, M., Fuzzi, S., Tagliavini, E., and Putaud, J.-P.: Chemical features and seasonal variation of fine aerosol water-soluble organic compounds in the Po Valley, Atmos. Environ., 36, 3691-3699, 2001.

Decesari, S., Fuzzi, S., Facchini, M. C., Mircea, M., Emblico, L., Cavalli, F., Maenhaut, W., Chi, X., Schkolnik, G., Falkovich, A., Rudich, Y., Claeys, M., Pashynska, V., Vas, G., Kourtchev, I., Vermeylen, R., Hoffer, A., Andreae, M. O., Tagliavini, E., Moretti, F., and Artaxo, P.: Characterization of the organic composition of aerosols from Rondnia, Brazil, during the LBASMOCC 2002 experiment and its representation through model compounds, Atmos. Chem. Phys., 6, 375-402, doi:10.5194/acp6-375-2006, 2006.

Decesari, S., Mircea, M., Cavalli, F., Fuzzi, S., Moretti, F., Tagliavini, E., and Facchini, M. C.: Source attribution of watersoluble organic aerosol by nuclear magnetic resonance spectroscopy, Environ. Sci. Technol., 41, 2479-2484, 2007.

Ding, X., Zheng, M., Yu, L., Luzhang, X., Weber, R., Yan, B., Russell, A. G., Edgerton, E. S., and Wang, X.: Spatial and Seasonal Trends in Biogenic Secondary Organic Aerosol Tracers and Water-Soluble Organic Carbon in the Southeastern United States, Environ. Sci. Technol., 42, 5171-5176, 2008.

Facchini, M. C., Mircea, M., Fuzzi, S., and Charlson, R. J.: Cloud albedo enhancement by surface-active organic solutes in growing droplets, Nature, 401, 257-259, doi:10.1038/45758, 1999.

Fuzzi, S., Andreae, M. O., Huebert, B. J., Kulmala, M., Bond, T. C., Boy, M., Doherty, S. J., Guenther, A., Kanakidou, M., Kawamura, K., Kerminen, V.-M., Lohmann, U., Russell, L. M., and Pöschl, U.: Critical assessment of the current state of scientific knowledge, terminology, and research needs concerning the role of organic aerosols in the atmosphere, climate, and global change, Atmos. Chem. Phys., 6, 2017-2038, doi:10.5194/acp-62017-2006, 2006.

de Gouw, J. A., Brock, C. A., Atlas, E. L., Bates, T. S., Fehsenfeld, F. C., Goldan, P. D., Holloway, J. S., Kuster, W. C., Lerner, B. M., Matthew, B. M., Middlebrook, A. M., Onasch, T. B., Peltier, R. E., Quinn, P. K., Senff, C. J., Stohl, A., Sullivan, A. P., Trainer, M., Warneke, C., Weber, R. J., and Williams, E. J.: Sources of particulate matter in the northeastern United States in summer: Direct emissions and secondary formation of organic matter in urban plumes, J. Geophys. Res., 113, D08301, doi:10.1029/2007JD009243, 2008.

Graber, E. R. and Rudich, Y.: Atmospheric HULIS: How humiclike are they? A comprehensive and critical review, Atmos. Chem. Phys., 6, 729-753, doi:10.5194/acp-6-729-2006, 2006.

Hakola, H., Tarvainen, V., Laurila, T., Hiltunen, V., Hellen, H., and Keronen, P.: Seasonal variation of VOC concentrations above a boreal coniferous forest, Atmos. Environ., 37, 1623-1634, 2003.

Hennigan, C. J., Sandholm, S., Kim, S., Stickel, R. E., Huey, L. G., and Weber, R. J.: Influence of Ohio River valley emissions on fine particle sulfate measured from aircraft over large regions of the eastern United States and Canada during INTEX-NA, J. Geophys. Res., 111, D24S04, doi:10.1029/2006JD007282, 2006.

Hennigan, C. J., Bergin, M. H., Dibb, J. E., and Weber, R. J.: Enhanced secondary organic aerosol formation due to water uptake by fine particles, Geophys. Res. Lett., 35, L18801, doi:10.1029/2008GL035046, 2008a.
Hennigan, C. J., Bergin, M. H., and Weber, R. J.: Correlations between water-soluble organic aerosol and water vapor: A synergistic effect from biogenic emissions?, Environ. Sci. Technol., 42, 9079-9085, 2008b.

Hennigan, C. J., Sullivan, A. P., Fountoukis, C. I., Nenes, A., Hecobian, A., Vargas, O., Peltier, R. E., Case Hanks, A. T., Huey, L. G., Lefer, B. L., Russell, A. G., and Weber, R. J.: On the volatility and production mechanisms of newly formed nitrate and water soluble organic aerosol in Mexico City, Atmos. Chem. Phys., 8, 3761-3768, doi:10.5194/acp-8-3761-2008, 2008 c.

Hennigan, C. J., Bergin, M. H., Russell, A. G., Nenes, A., and Weber, R. J.: Gas/particle partitioning of water-soluble organic aerosol in Atlanta, Atmos. Chem. Phys., 9, 3613-3628, doi:10.5194/acp-9-3613-2009, 2009.

Hsieh, L.-Y., Kuo, S.-C., Chen, C.-L., and Tsai, Y. I.: Origin of lowmolecular-weight dicarboxylic acids and their concentration and size distribution variation in suburban aerosol, Atmos. Environ., 41, 6648-6661, 2007.

Huang, X.-F., Yu, J. Z., He, L.-Y., and Yuan, Z.: Watersoluble organic carbon and oxalate in aerosols at a coastal urban site in China: Size distribution characteristics, sources, and formation mechanisms, J. Geophys. Res., 111, D22212, doi:10.1029/2006JD007408, 2006.

Jaffrezo, J.-L., Aymoz, G., Delaval, C., and Cozic, J.: Seasonal variations of the water soluble organic carbon mass fraction of aerosol in two valleys of the French Alps, Atmos. Chem. Phys., 5, 2809-2821, doi:10.5194/acp-5-2809-2005, 200.

Jimenez, J. L., Canagaratna, M. R., Donahue, N. M., et al.: Evolution of Organic Aerosols in the Atmosphere, Science, 326, 15251529, 2009.

Järvi, L., Hannuniemi, H., Hussein, T., Junninen, H., Aalto, P. P., Hillamo, R., Mäkelä, T., Keronen, P., Siivola, E., Vesala, T., and Kulmala, M.: The urban measurement station SMEAR III: Continuous monitoring of air pollution and surface-atmosphere interactions in Helsinki, Finland, Boreal Env. Res., 14(suppl. A), 86-109, 2009.

Kokkola, H., Sorjamaa, R., Peräniemi, A., Raatikainen, T., and Laaksonen. A.: Cloud formation of particles containing humic-like substances, Geophys. Res. Lett., 33, L10816, doi:10.1029/2006GL026107, 2006.

Kondo, Y., Miyazaki, Y., Takegawa, N., Miyakawa, T., Weber, R. J., Jimenez, J. L., Zhang, Q., and Worsnop, D. R.: Oxygenated and water-soluble organic aerosols in Tokyo, J. Geophys. Res., 112, D011203, doi:10.1029/2006JD007056, 2007.

Kulmala, M., Suni, T., Lehtinen, K. E. J., Dal Maso, M., Boy, M., Reissell, A., Rannik, Ü., Aalto, P., Keronen, P., Hakola, H., Bäck, J., Hoffmann, T., Vesala, T., and Hari, P.: A new feedback mechanism linking forests, aerosols, and climate, Atmos. Chem. Phys., 4, 557-562, doi:10.5194/acp-4-557-2004, 2004.

Kuokka, S., Teinilä, K., Saarnio, K., Aurela, M., Sillanpää, M., Hillamo, R., Kerminen, V.-M., Pyy, K., Vartiainen, E., Kulmala, M., Skorokhod, A. I., Elansky, N. F., and Belikov, I. B.: Using a moving measurement platform for determining the chemical composition of atmospheric aerosols between Moscow and Vladivostok, Atmos. Chem. Phys., 7, 4793-4805, doi:10.5194/acp-7-4793-2007, 2007.

Laakso, L., Hussein, T., Aarnio, P., Komppula, M., Hiltunen, V., Viisanen, Y., and Kulmala, M.: Diurnal and annual characteristics of particle mass and number concentrations in urban, rural 
and Arctic environments in Finland, Atmos. Environ., 37, 26292641,2003

Lanz, V. A., Alfarra, M. R., Baltensperger, U., Buchmann, B., Hueglin, C., and Prévôt, A. S. H.: Source apportionment of submicron organic aerosols at an urban site by factor analytical modelling of aerosol mass spectra, Atmos. Chem. Phys., 7, 1503-1522, doi:10.5194/acp-7-1503-2007, 2007.

Miyazaki, Y., Kondo, Y., Takegawa, N., Komazaki, Y., Fukuda, M., Kawamura, K., Mochida, M., Okuzawa, K., and Weber, R. J.: Time-resolved measurements of water-soluble organic carbon in Tokyo, J. Geophys. Res., 111, D23206, doi:10.1029/2006JD007125, 2006.

Miyazaki, Y., Kondo, Y., Shiraiwa, M., Takegawa, N., Miyakawa, T., Han, S., Kita, K., Hu, M., Deng, Z. Q., Zhao, Y., Sugimoto, N., Blake, D. R., and Weber, R. J.: Chemical characterization of water-soluble organic carbon aerosols at a rural site in the Pearl River Delta, China, in the summer of 2006, J. Geophys. Res., 114, D14208, doi:10.1029/2009JD011736, 2009.

Orsini, D., Ma, Y., Sullivan, A., Sierau, B., Baumann, K., and Weber, R.: Refinements to the particle-into-liquid sampler (PILS) for ground and airborne measurements of water-soluble aerosol composition, Atmos. Environ., 37, 1243-1259, 2003.

Ovadnevait, J., Kvietkus, K., and Maršalka, A.: 2002 summer fires in Lithuania: Impact on the Vilnius city air quality and the inhabitants health, Sci. Total Environ., 356, 11-21, 2006.

Parshintsev, J., Räsänen, R., Hartonen, K., Kulmala, M., and Riekkola, M.-L.: Analysis of organic compounds in ambient aerosols collected with the particle-into-liquid sampler, Boreal Env. Res., 14, 630-640, 2009.

Peltier, R. E., Weber, R. J., and Sullivan, A. P.: Investigating a Liquid-Based Method for Online Organic Carbon Detection in Atmospheric Particles, Aerosol Sci. Technol., 41(12), 11171127, 2007.

Saarikoski, S., Sillanpää, M., Sofiev, M., Timonen, H., Saarnio, K., Teinilä, K., Karppinen, A., Kukkonen, J., and Hillamo, R.: Chemical composition of aerosols during a major biomass burning episode over northern Europe in spring 2006: Experimental and modeling assessments, Atmos. Environ., 41, 3577-3589, 2007.

Saarikoski, S., Timonen, H., Saarnio, K., Aurela, M., Järvi, L., Keronen, P., Kerminen, V.-M., and Hillamo, R.: Sources of organic carbon in fine particulate matter in northern European urban air, Atmos. Chem. Phys., 8, 6281-6295, doi:10.5194/acp-86281-2008, 2008.

Saarnio, K., Aurela, M., Timonen, H., Saarikoski, S., Teinilä, K., Mäkelä, T., Sofiev, M., Koskinen, J., Aalto, P. P., Kulmala, M., Kukkonen, J., and Hillamo, R.: Chemical composition of fine particles in fresh smoke plumes from boreal wild-land fires in Europe, Sci. Total Environ., 405, 2527-2542, 2010.

Saxena, P. and Hildemann, L. M.: Water-soluble organics in atmospheric particles: a critical review of the literature and application of thermodynamics to identify candidate compounds, J. Atmos. Chem., 24, 57-109, 1996.

Sillanpää, M., Saarikoski, S., Hillamo, R., Pennanen, A., Makkonen, U., Spolnik, Z., Van Grieken, R., Koskentalo, T., and Salonen, R. O.: Chemical composition, mass size distribution and source analysis of long-range transported wildfire smokes in Helsinki, Sci. Total Environ., 350, 119-135, 2005.

Sorooshian, A., Varutbangkul, V., Brechtel, F. J., Ervens, B., Fein- gold, G., Bahreini, R., Murphy, S. M., Holloway, J. S., Atlas, E. L., Buzorius, G., Jonsson, H., Flagan, R. C., and Seinfeld, J. H.: Oxalic acid in clear and cloudy atmospheres: Analysis of data from International Consortium for Atmospheric Research on Transport and Transformation 2004, J. Geophys. Res., 111, D23S45, doi:10.1029/2005JD006880, 2006.

Sorooshian, A., Ng, N. L., Chan, A. W. H., Feingold, G., Flagan, R. C., and Seinfeld, J. H.: Particulate organic acids and overall water-soluble aerosol composition measurements from the 2006 Gulf of Mexico Atmospheric Composition and Climate Study (GoMACCS), J. Geophys. Res., 112, D13201, doi:10.1029/2007JD008537, 2007.

Stohl, A. and Wotawa, G.: A method for computing single trajectories representing boundary layer transport, Atmos. Environ., 29, 3235-3239, 1995.

Sueper, D.: ToF-AMS High resolution analysis softwareavailable online at: http://cires.colorado.edu/jimenez-group/ ToFAMSResources/ToFSoftware/index.html, 2009.

Sullivan, A. P., Peltier, R. E., Brock, C. A., de Gouw, J. A., Holloway, J. S., Warneke, C., Wollny, A. G., and Weber, R. J.: Airborne measurements of carbonaceous aerosol soluble in water over northeastern United States: Method development and an investigation into water-soluble organic carbon sources, J. Geophys. Res., 111, D23S46, doi:10.1029/2006JD007072, 2006.

Szidat, S., Jenk, T. M., Synal, H. -A., Kalberer, M., Wacker, L., Hajdas, I., Kasper-Giebl, A., and Baltensperger, U.: Contributions of fossil fuel, biomass-burning, and biogenic emissions to carbonaceous aerosols in Zurich as traced by ${ }^{14} \mathrm{C}$, J. Geophys. Res. 111, D07206, doi:10.1029/2005JD006590, 2006.

Szidat, S., Ruff, M., Perron, N., Wacker, L., Synal, H.-A., Hallquist, M., Shannigrahi, A. S., Yttri, K. E., Dye, C., and Simpson, D.: Fossil and non-fossil sources of organic carbon (OC) and elemental carbon (EC) in Göteborg, Sweden, Atmos. Chem. Phys., 9, 1521-1535, doi:10.5194/acp-9-1521-2009, 2009.

Tunved, P., Hansson, H. -C., Kerminen, V.-M., Ström, J., Dal Maso, M., Lihavainen, H., Viisanen, Y., Aalto, P. P., Komppula, M. and Kulmala, M.: High natural aerosol loading over boreal forests, Science, 312, 261-263, 2006.

Ten Brink, H., Maenhaut, W., Hitzenberger, R., Gnauk, T., Spindler, G., Even, A., Chi, X., Bauer, H., Puxbaum, H., Putaud, J., Tursic, J., and Berner, A.: INTERCOMP2000: the comparability of methods in use in Europe for measuring the carbon content of aerosol, Atmos. Environ., 38, 6507-6519, 2004.

Turpin, B. J. and Lim, H.-J.: Species contributions to $\mathrm{PM}_{2.5}$ mass concentrations: revisiting common assumptions for estimating organic mass, Aerosol Sci. Technol., 35, 602-610, 2001.

Viana, M., Maenhaut, W., ten Brink, H. M., Chi, X., Weijers, E., Querol, X., Alastuey, A., Mikuška, P., Veea, Z.: Comparative analysis of organic and elemental carbon concentrations in carbonaceous aerosols in three European cities, Atmos. Environ., 41, 5972-5983, 2007.

Warren, B., Austin, R., and Cocker III, D. R.: Temperature dependence of secondary organic aerosol, Atmos. Environ., 43, 35483555, 2009.

Watson, J. G., Chow, J. C., Lu, Z., Fujita, E. M., Lowenthal, D. H., and Lawson, D. R.: Chemical mass balance source apportionment of $\mathrm{PM}_{10}$ during the Southern California air quality study, Aerosol Sci. Technol., 21, 1-36, 1994.

Weber, R. J. Orsini, D., Daun, Y., Lee, Y.-N., Klotz, P. J., and Brech- 
tel, F.: A Particle-into-Liquid Collector for Rapid Measurement of Aerosol Bulk Chemical Composition, Aerosol Sci. Technol., 35, 718-727, 2001.

Weber, R. J., Sullivan, A. P., Peltier, R. E., Russell, A., Yan, B., Zheng, M., de Gouw, J., Warneke, C., Brock, C., Holloway, J. S., Atlas, E. L., and Edgerton, E.: A study of secondary organic aerosol formation in the anthropogenicinfluenced southeastern United States, J. Geophys. Res., 112, D13302, doi:10.1029/2007JD008408, 2007.
Yang, H., Yu, J. Z., Ho, S. S. H., Xu, J., Wu, W., Wan, C. H., Wang, X., Wang, X. and Wang, L.: The chemical composition of inorganic and carbonaceous materials in $\mathrm{PM}_{2.5}$ in Nanjing, China, Atmos. Environ., 39, 3735-3749, 2005.

Zhang, Y., Schauer, J., Shafer, M., Hannigan, M., and Dutton, S.: Source apportionment of in Vitro Reactive Oxygen Species Bioassay Activity from Atmospheric Particulate Matter, Environ. Sci. Technol., 42, 7502-7509, 2008. 